\title{
PEMANFAATAN MEDIA PEMBELAJARAN PADA MATA PELAJARAN MENGOLAH MAKANAN KONTINENTAL DI SMK NEGERI 3 PADANGSIDIMPUAN
}

\author{
JULIANA SIREGAR \\ julie.harlie02@gmail.com
}

\begin{abstract}
Abstrak: Mata pelajaran Mengolah Makanan Kontinental merupakan mata pelajaran yang lebih mengarah kepada pelajaran praktek guna pembentukan keterampilan siswa, sehingga pemanfaatan media sangat mendukung terhadap hasil belajar siswa. Media dalam pembelajaran Mengolah Makanan Kontinenntal tidak dilihat dari segi kecanggihan medianya, tetapi lebih kepada fungsi dan peranannya dalam membantu efektifitas pengajaran. Media yang dapat digunakan dalam proses pembelajaran adalah media grafis dan media asli/tiruan, dimana dalam media grafis guru bisa memilih media gambar, chart, poster atau media papan. Begitu juga dengan media asli/tiruan, guru bisa memilih benda sebenarnya sebagai media atau benda tiruan yang menyerupai benda asli.

Dalam penelitian ini peneliti menggunakan pendekatan kualitatif, dimana data diperoleh dari hasil wawancara langsung dengan informan penelitian, yaitu guru mata pelajaran Mengolah Makanan Kontinental, siswa dan kepala sekolah. Kemudian sebagai data pendukung penulis mendokumentasikan hal-hal yang dianggap mendukung data penelitian. Alat yang digunakan dalam pengumpulan data adalah panduan observasi, panduan wawancara, pena/pensil dan kamera sebagai alat pendukung. Selanjutnya hasil penelitian dianalisis berdasarkan cara kerja yang dilakukan model Miles dan Huberman yaitu reduksi, penyajian, kemudian verifikasi/penarikan kesimpulan.

Hasil penelitian yang diperoleh menunjukkan bahwa guru-guru mata pelajaran Mengolah Makanan Kontinental sudah merencanakan menggunakan media pembelajaran, hal ini dapat dilihat dalam Rencana Pelaksanaan Pembelajaran yang telah disusun oleh guru tersebut. Penggunaan media oleh guru sudah sesuai dengan perencanaan yang sudah disusun sebelumnya. Media papan tulis merupakan media yang paling sering digunakan karena dianggap praktis oleh guru. Sedangkan flip chart merupakan media yang tidak pernah digunakan oleh guru, karena papan flip chart tidak tersedia di sekolah. Penggunaan media pembelajaran oleh guru masih terbatas disebabkan media yang tersedia di sekolah belum memadai.
\end{abstract}

Kata Kunci : Media, Pembelajaran, Mengolah Makanan, Kontinental

\section{A. Pendahuluan}

Proses pembelajaran pada hakekatnya adalah proses komunikasi yang dapat diartikan sebagai penyampaian informasi pada siswa. Proses komunikasi dalam suatu kegiatan pembelajaran merupakan komunikasi timbal balik yang diciptakan oleh guru dan murid sehingga pesan yang disampaikan dalam bentuk materi pelajaran dapat dipahami dengan baik. Proses komunikasi tidak selalu dapat berjalan lancar dan bahkan proses komunikasi dapat menimbulkan kebingungan dan salah pengertian sehingga terjadi kegagalan dalam berkomunikasi.

Keberhasilan siswa dalam pembelajaran ditentukan oleh proses pembelajaran yang dilaksanakan, dimana dalam pelaksanaannya dituntut adanya kemampuan profesional guru, salah satunya dalam menggunakan media. Guru yang profesional E-ISSN: 2657-0300 Lembaga Penelitian dan Penerbitan Hasil Penelitian Ensiklopedia $\quad 51$ 
seharusnya memperhatikan akan pentingnya peranan media dalam proses pembelajaran, sebab dengan adanya media yang baik diharapkan pembelajaran yang diberikan dapat diserap semaksimal mungkin oleh siswa. Materi pelajaran yang diberikan secara verbal saja kemungkinan materi pelajaran tersebut diserap oleh siswa relatif sangat kecil. Hal ini disebabkan karena pelajaran yang diberikan secara abstrak, dan siswa harus dapat menafsirkan pelajaran tersebut, adakalanya penafsiran tersebut berhasil dan adakalanya tidak.

Media pembelajaran dapat mengatasi hambatan dalam berkomunikasi serta mempersatukan pengamatan siswa. Media yang digunakan oleh guru dalam tugasnya sebagai penyampai pesan memiliki berbagai karakteristik, sehingga seorang guru dituntut untuk mengetahui dan menguasai kriteria penggunaan media tersebut agar ia dapat lebih mudah memilih dan menentukan media yang lebih tepat, sebab apabila guru tidak dapat menyesuaikan media yang ia gunakan didalam proses pembelajaran maka hasil yang diperoleh tidak akan maksimal.

SMK Negeri 3 Padangsidimpuan merupakan sekolah menengah kejuruan kelompok pariwisata yang terdiri dari tiga jurusan yaitu, Tata Boga, Tata Busana, dan Tata Kecantikan Rambut. Setiap jurusan terdapat Mata Pelajaran Produktif. Mengolah Makanan Kontinental merupakan salah satu Mata Pelajaran Produktif Tata Boga yang lebih mengarah pada keterampilan mengolah makanan asing (Negara Amerika dan Eropa), sehingga siswa dituntut untuk memiliki pengetahuan dan keterampilan yang handal sehingga dapat bersaing di dunia kerja nantinya.

Pada mata pelajaran Mengolah Makanan Kontinental sebelum belajar praktek maka terlebih dahulu belajar teori yang berhubungan dengan apa yang akan dipraktekkan. Dalam pembelajaran teori sebelum praktek tersebut sangat tidak efisien jika guru hanya menggunakan metode ceramah tanpa bantuan media mengingat banyaknya jenis bumbu dan peralatan asing yang sebelumnya belum dikenal siswa. Oleh sebab itu maka guru dituntut untuk memanfaatkan media pembelajaran, apalagi pada mata pelajaran Mengolah Makanan Kontinental yang lebih mengarah kepada keterampilan pengolahan masakan asing.

Namun pada kegiatan kunjungan yang dilakukan di SMK Negeri 3 Padangsidimpuan, kenyataan yang terlihat dalam proses pembelajaran, ceramah menjadi pilihan utama strategi belajar. Di dalam proses pembelajaran media yang digunakan guru kurang menarik perhatian siswa, kurangnya perencanaan guru dalam menggunakan media pembelajaran yang diketahui apabila dimanfaatkan dengan optimal dapat meningkatkan efisiensi proses pembelajaran. Selain kurangnya perencanaan guru dalam menggunakan media pembelajaran, media yang tersedia di sekolah juga masih kurang memadai.

\section{Media Pembelajaran}

Media berasal dari kata latin medium yang berarti perantara atau pengantar. Jalius dalam bukunya (2009:73) menulis "media komunikasi yang digunakan dalam dunia pendidikan umumnya disebut media pembelajaran". Selanjutnya Arsyad (2009:7) menulis "media pembelajaran memilki pengertian alat bantu pada proses belajar baik di dalam maupun di luar kelas".

Berdasarkan uraian pendapat diatas dapat disimpulkan bahwa media pembelajaran merupakan segala sesuatu yang dapat menunjang proses pembelajaran sehingga dapat mengefektifkan komunikasi dan interaksi antara guru dan siswa 
kemudian materi yang disampaikan dapat diterima oleh siswa sehingga tercapai tujuan yang diinginkan.

Arsyad (2009:25) mengemukakan beberapa manfaat praktis media pembelajaran sebagai berikut:

a. Media pembelajaran dapat memperjelas penyajian pesan dan informasi sehingga dapat memperlancar dan meningkatkan proses dan hasil belajar.

b. Media pembelajaran dapat meningkatakan dan mengarahkan perhatian anak sehingga dapat menimbulkan motivasi belajar, interaksi yang lebih langsung antara siswa dan lingkungannya, dan kemungkinan siswa untuk belajar sendiri- sendiri sesuai dengan kemampuan dan minatnya.

c. Media pembelajaran dapat mengatasi keterbatasan indera, ruang, dan waktu.

d. Media pembelajaran dapat memberikan kesamaan pengalaman kepada siswa tentang peristiwa- peristiwa di lingkungan mereka, serta memungkinkan terjadinya interaksi langsung dengan guru, masyarakat, dan lingkungannya. Misalnya melalui karyawisata, kunjungan- kunjungan ke museum atau kebun binatang.

Selain Hamalik dan Arsyad, Jalius (2009:82) dalam bukunya juga menulis beberapa manfaat media sebagai berikut:

a. Penyampaian materi pelajaran dapat diseragamkan. Penyampaian suatu konsep yang bersifat abstrak dapat menyebabkan penafsiran yang berbeda- beda antara guru yang satu dengan guru yang lain. Dengan menggunakan media, penafsiran yang beragam itu dapat dikurangi, sehingga dapat disampaikan kepada siswa secara seragam. Setiap siswa yang melihat atau mendengar uraian tentang suatu ilmu melalui media yang sama akan menerima informasi yang sama.

b. Proses instruksional menjadi lebih menarik. Media yang baik dapat membanggkitkan keingintahuan siswa, merangsangnya untuk bereaksi terhadap penjelasan guru sehingga menghasilkan pemahaman yang baik.

c. Proses belajar siswa menjadi interaktif. Media yang baik dapat menimbulkan terjadinya komunikasi dua arah.

d. Jumlah waktu pembelajaran dapat dikurangi. Waktu yang dihabiskan guru untuk menjelaskan suatu konsep yang bersifat abstrak dapat dipersingkat, misalnya dengan membawa model dari benda yang dimaksud.

e. Peran guru dapat berobah ke arah yang lebih positif dan produktif, seperti memberi motivasi, penasihat atau manajer proses belajar mengajar.

Menurut pendapat di atas dapat diambil kesimpulan bahwa media pembelajaran dapat menarik dan memperbesar perhatian siswa terhadap materi pelajaran, memungkinkan terjadinya kontak langsung antara siswa dengan guru, mengurangi adanya verbalisme, serta membantu perkembangan pikiran siswa secara teratur tentang hal yang mereka alami. Melalui media pembelajaran siswa dapat melihat lebih nyata tujuan dari pembelajaran yang diberikan guru, sehingga materi tersebut tidak lagi hanya dalam khayalan siswa.

Pemanfaatan media pembelajaran merupakan suatu proses dalam pemanfaatan media, dimana dalam proses pembelajaran guru tidak hanya menggunakan media yang ada tetapi guru juga harus melakukan pemanfaatan media yang meliputi: perencanaan media pembelajaran dan penggunaan media dalam proses pembelajaran. Hal ini sesuai dengan pendapat Sadiman (2003: 181) "supaya media pembelajaran itu 
efektif maka pemanfaatan media harus direncanakan dan digunakan secara sistematik".

Pendidikan kejuruan bertujuan untuk meningkatkan kecerdasan, pengetahuan, kepribadian, akhlak mulia, serta keterampilan peserta didik untuk hidup mandiri dan mengikuti pendidikan lebih lanjut sesuai dengan program kejuruannya. Agar dapat bekerja secara efektif dan efisien serta mengembangkan keahlian dan keterampilan, mereka harus memiliki stamina yang tinggi, menguasai bidang keahliannya dan dasardasar ilmu pengetahuan dan teknologi, memiliki etos kerja yang tinggi, dan mampu berkomunikasi sesuai dengan tuntutan pekerjaannya, serta memiliki kemampuan mengembangkan diri. Struktur kurikulum pendidikan kejuruan Sekolah Menengah Kejuruan (SMK) diarahkan untuk mencapai tujuan tersebut.

Mata Pelajaran Produktif Tata Boga SMK N 3 Padangsidimpuan disusun dalam kompetensi spektrum yang terdiri dari beberapa kompetensi kejuruan, salah satu diantaranya adalah Mengolah Makanan Kontinental. Mengolah Makanan Kontinental merupakan kompetensi yang mempelajari tentang pola makan, waktu, bahan, bumbu, alat pengolahan, dan teknik pengolahan makanan Negara Amerika dan Eropa. Selain itu dalam Mengolah Makanan Kontinental juga dipelajari cara mengolah dan menyajikan makanan Negara Amerika dan Eropa.

Berdasarkan uraian di atas dapat diketahui mata pelajaran Mengolah Makanan Kontinental merupakan mata pelajaran yang berhubungan dengan makanan Negara yang sangat asing kebiasaan makannya dengan Negara Indonesia. Oleh sebab untuk menunjang keberhasilan siswa dalam proses pembelajaran Mengolah Makanan Kontinental maka dituntut profesional guru dalam pemanfaatan media pembelajaran.

\section{B. Metode Penelitian}

Penelitian ini diteliti dengan menggunakan pendekatan kualitatif, yaitu prosedur penelitian yang menghasilkan data deskriptif berupa kata-kata tertulis atau lisan orang-orang dan perilaku yang dapat diamati

Penelitian dilakukan di SMK Negeri 3 Padangsidimpuan yang berlokasi di Jalan Silandit no. 33 Kota Padangsidimpua, Sumatera Utara.

Penentuan informan ditetapkan setelah peneliti terjun langsung ke lapangan berdasarkan tujuan, kebutuhan dan relevansi. Mereka yang dijadikan sasaran informan adalah kepala sekolah, wakil kepala sekolah bidang kurikulum, guru bidang studi dan beberapa orang siswa.

Instrumen kunci dalam penelitian ini adalah peneliti sendiri yang langsung terlibat dalam penelitian dengan menggunakan teknik observasi, wawancara, dan dokumentasi.

Pembuktian kebenaran temuan penelitian akan dilakukan dengan cara triangulasi data. Moleong (2006) triangulasi dapat dilakukan dengan cara : (1) Membandingkan data hasil pengamatan dengan data hasil wawancara, (2) Membandingkan apa yang dikatakan orang di depan umum dengan apa yang dikatakan secara pribadi, (3) Membandingkan apa yang dikatakan orang tentang situasi penelitian dengan apa yang dikatakan sepanjang waktu, (4) Membandingkan keadaan dan perspektif seseorang dengan berbagai pendapat dan pandangan orang lain, (5) Membandingkan hasil wawancara dengan suatu isi dokumen yang berkaitan.

Analisis hasil penelitian dilakukan selama pengumpulan data di lapangan berlangsung. Analisis yang digunakan oleh penulis adalah analisis model Miles and 
Huberman, yaitu Data Reduction (Reduksi Data), Data Display (Penyajian Data), dan Verification/ Conclusion Drawing ( Verifikasi/Penarikan Kesimpulan.

\section{Hasil}

\section{Perencanaan Media Pembelajaran pada Mata Pelajaran Mengolah Makanan Kontinental di SMK Negeri 3 Padangsidimpuan}

Hasil penelitian, berupa wawancara, observasi dan dokumentasi diperoleh informasi bahwa sebelum menggunakan media guru terlebih dahulu merencanakan media. Perencanaan media dituangkan dalam Rencana Pelaksanaan Pembelajaran. Dalam merencanakan media guru selalu mempertimbangkan tujuan pelajaran, isi pelajaran, memilih media yang sesuai dengan kemampuan, dan mempertimbangkan kualitas media yang akan digunakan. Hal ini sesuai dengan pendapat Arsyad (1997:75) "dalam perencanaan media pembelajaran ada beberapa kriteria yang harus dipenuhi: 1) sesuai dengan tujuan yang ingin dicapai, 2) mendukung terhadap isi pelajaran, 3) terampil menggunakannya, 4) media memiliki kualitas yang baik".

Selain pendapat Arsyad, Jalius (2009:86) juga mengemukakan pertimbangan-pertimbangan dalam memilih media:

a. Faktor siswa. Jumlah siswa yang mengikuti pembelajaran ikut mempengaruhi penentuan media apa yang akan digunakan dalam proses pembelajaran. Bila jumlah siswa besar, sebaiknya digunakan media infokus dengan power points. Sebaliknya, jika siswa jumlahnya sedikit dapat menggunakan flip chart dan papan tulis.

b. Faktor isi dan materi pelajaran. Hal yang perlu diperhatikan disini adalah apakah pelajaran tersebut menuntut terjadinya komunikasi satu arah atau dua arah.

c. Tujuan belajar yang akan dicapai. Maksudnya apakah tujuan belajar untuk melatih keterampilan manual atau penguasaan konsep (pemahaman). Keterampilan manual memerlukan praktek. Guru mendemonstrasikan dengan media asli secara langsung, kemudian siswa mempraktekkan dengan meniru gerakan atau sesuai prosedur kerja yang disediakan guru.

d. Fungsi guru adalah untuk mengkomunikasikan informasi kepada siswa. Untuk itu guru harus menggunakan bebrapa saluran sensori seperti saluran penglihatan dan pengrabaan selama proses belajar berlangsung. Setelah itu harus dilakukan observasi untuk memeriksa umpan balik untuk meyakinkan apakah komunikasi sudah berlangsung dan tujuan belajar sudah tercapai.

Dalam memilih media pembelajaran, sejumlah faktor yang terkait harus dipertimbangkan, yang terpenting harus dilihat apakah media yang dipilih tersebut tepat dipakai untuk mencapai tujuan belajar. Selanjutnya, dipertimbangkan dari segi biaya, ketersediaan media yang ada, faktor siswa dan guru, serta suasana kelas seperti cahaya dan sirkulasi udara.

Khusus dalam pembelajaran Mengolah Makanan Kontinental, perlu dipikirkan perencanakan media yang menarik untuk digunakan dalam proses pembelajaran. Usaha yang dapat dilakukan antara lain membuat slide-slide menarik atau mencari gambar-gambar menarik seputar makanan Kontinental sehingga hal tersebut dapat menarik minat siswa untuk mengetahui lebih banyak lagi tentang makanan Kontinental. 


\section{Penggunaan Media Pembelajaran pada Mata Pelajaran Mengolah Makanan Kontinental di SMK Negeri 3 Padangsidimpuan}

Media pembelajaran pada mata pelajaran produktif Tata Boga di SMK Negeri 3 Padangsidimpuan sudah sering digunakan, namun penggunaan media tersebut belum maksimal disebabkan oleh faktor keterbatasan media yang disediakan sekolah. Hal ini diungkapkan guru Mengolah Makanan Kontinental 1, 2 dan 3 "media pembelajaran Mengolah Makanan Kontinental sudah tersedia disekolah, namun jumlahnya masih terbatas". Media yang paling sering digunakan adalah media papan tulis, karena media tersebut oleh guru dianggap sebagai media yang paling praktis dan sederhana dalam penggunaannya. Hal ini sesuai dengan pendapat Arsyad (2003:40) "media papan tulis merupakan media pajang yang paling sederhana dan hampir selalu tersedia".

Sebelum menggunakan media, hal yang seharusnya dilakukan guru adalah mempersiapkan bahan sebelum menggunakan media. Dari hasil wawancara penulis dengan guru mata pelajaran Mengolah Makananan Kontinental, guru sudah melakukan persiapan sebelum menggunakan media, yaitu berupa persiapan power points jika akan menggunakan infokus dalam pembelajaran.

Selain melakukan persiapan, guru juga memperhatikan kegiatan belajar selama menggunakan media, yaitu dengan cara menghindari penggunaan media yang belum familiar atau masih asing. Hal ini sesuai dengan pendapat Jalius (2009:83) "Dalam memilih media, guru harus familiar dengan media tersebut".

Selain melakukan persiapan dan memperhatikan kegiatan selama menggunakan media, guru juga melakukan kegiatan tindak lanjut untuk mengetahui tingkat pemahan siswa dengan menggunakan media pembelajaran. Kegiatan tindak lanjut yang dilakukan guru adalah berupa test atau tanya jawab tetang materi yang baru disampaikan.

Dari beberapa uraian diatas, kegiatan yang dilakukan guru selama penggunaan media, sesuai dengan pendapat Sadiman (2003: 189) tentang penggunaan media, "supaya media dapat digunakan secara efektif dan efisien, ada langkah utama yang perlu diikuti dalam menggunakan media pembelajaran, yaitu: 1) persiapan sebelum menggunakan media, 2) kegiatan selama menggunakan media, 3) Kegiatan tindak lanjut".

Dari Penelitian ini juga dapat diketahui bahwa dengan penggunaan media pembelajaran proses pembelajaran akan terasa menyenangkan bagi siswa sehingga materi mudah dipahami. Hal ini diungkapkan siswa ketika peneliti melakukan wawancara dengan siswa 1 dan 2. Siswa 1 (Nurul) "pelajaran akan terasa menyenangkan jika guru menggunakan media". Siswa 2 (Hamidi) "akan lebih mudah memahami jika ada media". Hasil wawancara tersebut juga sesuai dengan pendapat Arsyad (2003:16) "Media pengajaran membawa dan membangkitkan rasa senang dan gembira bagi murid-murid dan memperbarui semangat mereka".

\section{Daftar Pustaka}

Ahmad, Rohani. 1997. Media Instruksional Edukatif. Jakarta: Rineka Cipta. Ali, Mohammad H. 1993. Strategi Penelitian Pendidikan. Bandung: Angkasa Bandung. 
Azhar, Arsyad. 2009. Media Pembelajaran. Jakarta: PT. Raja Grafindo Persada.

Benny Agus Pribadi. 2005. Ragam Media Dalam Pembelajaran. Jakarta: PAU - PPAI Universitas Terbuka.

Jalius, Ellizar. 2009. Pengembangan Program Pembelajaran. Padang: UNP Press.

Hamalik, Oemar. 2005. Perencanaan Pengajaran Berdasarkan Pendekatan Sistem. Jakarta: Bumi Aksara.

Irawan, Prasetya. 1999. Logika dan Prosedur Penelitia: Penganntar Teori dan Panduan Praktis Penelitian Sosial bagi Mahasiswa dan Peneliti Pemula. Jakarta: STIA-LAN Press.

Nasution, S. 1995. Metode Research. Bandung: Jemmars bandung.

Sadiman, Arif. 2003. Media Pendidikan, Pengertian, Pengembangan, dan Pemanfaatannya. Jakarta: PT. Raja Grafindo Persada.

Yusuf, Muri A. 2009. Metodologi Penelitian: UNP Press. 